\title{
Learning Outcomes Viewed from a Learning Process through an ICT-Based Learning Group
}

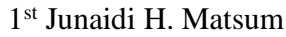

prof.junaidimatsum@gmail.com

\begin{abstract}
Technology is becoming commonplace entities in both our personal and professional lives. Although the use of ICT by economy teacher is still not widespread, yet it has the potential to profoundly enrich and improve students' skill, as well as engage and reinforce them in learning. Thus, this research sought to find out: (1) how the learning process through ICTbased learning group is performed on the economy subject in SMAN 1 Sungai Raya Kepulauan of Bengkayang Regency; (2) how high are the learning outcomes of economy subject in SMAN 1 Sungai Raya Kepulauan of Bengkayang Regency; (3) is there are any influences of a learning process through an ICT-based learning group towards the learning outcomes of economy subject in SMAN 1 Sungai Raya Kepulauan of Bengkayang Regency. This research employed descriptive method with interrelationship studies. The research was carried out in SMAN 1 Sungai Raya Kepulauan of Bengkayang Regency in the academic year of 2016/2017. The subject of research was the students in SMAN 1 Sungai Raya Kepulauan of Bengkayang Regency who are officially enrolled in Social Science Major splitted into 7 study groups $(210$ students). The sample was drawn through probability sampling technique. Techniques and data collection were through questionnaire, interview, observation, and documentary study. Before conducting the regression analysis, the researcher carried out the classical assumption test. Meanwhile the data analysis was done through SPSS v.16.The acquired conclusions were (1) the learning process through ICT-based learning group by referring to students $(67.86)$ belongs to good classification. (2) The learning outcomes of economy subject are 75.13 in average value which included in medium category. (3) The learning process through ICT-based learning group generates a considerable influence towards the learning outcomes of economy subject.
\end{abstract}

Keywords-learning group, ICT, learning outcomes.

\section{INTRODUCTION}

Generally speaking, learning group or group work is aparticular group of students who organize themselves and work together to achieve the objectives of study. Group work, collaborative learning, and cooperative learning are similar terms to depict the condition in which the students working together in an adequate small group that everyone can participate on a collective task being assigned by the teacher (Cohen, 1994). The ultimate purpose of this activity is that to increase their motivation which in turn result a more successful learning outcomes because learning process is conducted collaboratively instead of individually. The previous literatures clearly state that group learning is superior to individual learning; it manages academic heterogeneity among students with a variety of achievement in academic skills (Moore \& Gunderson, 2008; Cohen, 1994).In this way, learning group is better to be consisted of heterogeneous members that include high, medium, and low capabilities with various background social-economy united in one group.

Earlier Internet is used to collect information only but as time and technology changing fast, lots of new trends is coming. Nowadays, large number of people use Internet in numerous fields and domainds, and its use give a great potential for educational uses. The learning process through ICT has made the students to be able to use internet. The technology world, especially computer has become highly developed at present which not used in the learning process of self instruction alone but also used in wider framework such as education media. According to Balaji and Chakrabarti (2010), currently, management education has been experiencing an increased interest in using Internet and Communication Technology (ICT) tools.

It is generally argued thatICTs has considerably affected the education field, which have undoubtedly affected teaching, learning and research (Yusuf, 2005). A great deal of research has proven the benefits to the quality of education (Al-Ansari, 2006). Sudjana (2013) asserted that the aim of learning process through media is for the learning materials to have a clear explanation, thus, the students will have more comprehension towards them; as a result, able to improve their learning outcomes. Therefore, the utilization of ICT in education field is inevitability. Internet has become reliable and useful ways or facilities for the necessities of researchers, teachers, and students. In this sense, the characteristics and potentials of electronic should be understood to be 
used in optimal manner for the needs in education, especially in learning process.

The implementation of a learning process through ICT-based learning group is a variation of learning that expected to improve the students condition to be more active and motivated in learning. On the other hand, there are still teachers who shut themselves to learn and fully ignore the use of ICT in the classroom. The actual fact is that the learners nowadays have become the native of technology yet the teachers are far less skilled and knowledgeable than them. Thus, the teaching and learning process remains in traditional way for years. Neglecting a learning model implementation is the beginning of the boredom issue; conversely, an open attitude towards changes is the beginning of the emergence of learning enthusiasm (Dahlan, 2014). Joyce and Weil (1990) stated that the one-way conventional learning process which solely transfers science, norms, cultural values, and others from the teachers to students is started to acquire doubt on its effectiveness. Traditional printed books are arguably not an adequate vehicle for dealing with the $21^{\text {st }}$ century learning era (Holmes \& Gardner, 2006). In furtherance to this, meeting the challenges of education in the twenty-first century learning is unquestionably should be the major attention for teachers, particulary for economy subject teachers.

Considering the aforementioned fact about ICTs, thus, this research sought to find out (1) the learning process through ICT-based learning group, (2) the learning outcomes, and (2) the learning impacts through ICT-based learning group towards the learning outcomes. Meanwhile, the significance of this study are classified into three parts: (a) For student, encouraging students to utilize the study group in general and e-learning media in particular; (b) For teacher, providing a feedback regarding the learning process through ICT-based learning group which later directed to be more professional in learning process/activity; (c) For school, improving the education level and standard.

\section{METHOD}

This research employed descriptive method with interrelationship studies. The independent variable is a learning process through ICT-based learning group. The dependent variable is the learning outcomes of economy subject. The research was carried out in SMAN 1 Sungai Raya Kepulauan of Bengkayang Regency in the even semester of academic year of $2016 / 2017$. The subject of research is the entire students who officially enrolled in Social Science Major on 7 study groups (210 students). The sample was determined through probability sampling technique (Nawawi, 2015). A probability sample, as it draws randomly from the wider population, will be useful to make generalization because it seeks representativeness of the wider population (Cohen, Manion, \& Morison, 2007). The first stage was by randomly drawing a class that would become a sample; XI Science Major 2 is selected. The second stage was determining the students as the respondents resulted in 28 students of XI Science Major 2.

With regard to techniques and data collection, theywere accomplished through questionnaire, interview, observation, and documentary techniqueusing note-sheet. The hypothesis was formulated and tested through regression analysis. The data analysis was performed by using SPSS v.16 program. Nevertheless, before doing the data analysis, the researcher conducted classical assumption test.

\section{RESULT AND DISCUSSION}

According to the results of data analysis and hypothesis testing, it is known that (1) the level of a learning process through ICT-based learning group in accordance with most of students' opinion is $67.86 \%$ from 28 students belongs to good classification. This result is supported by the teacher compatibility in implementing the steps of learning in accordance with the predetermined plan. The formulation of activity steps of learning activity is the most important part of learning process planning and is also becoming the guideline for teacher to perform the learning process which include: (a) the preliminary activities, i.e. teacher conducts an apperception, proposes learning objectives and materials coverage, as well as motivates the students to be more active. (b) The core activities that include class preparation, provide information available in internet regarding the materials topic to be discussed, form heterogeneous groups, order each study group to discuss the materials, request each group to utilize the media with a teacher supervision, request each group to present learning materials by utilizing the media, request each group to select its speaker, while the other members also prepare to provide response over the question from another group. (c) Closing activities, in outline include reflection stage, teacher asks for information from students in class regarding a learning experience, the stage of concluding the materials, and the stage of final evaluation, teacher conducts written post test, and assigns students to study the materials that will be discussed on the next day. (2) The learning outcomes of students are derived from the list of student grade in the ledger, with 75.13 average value of two daily exams of XI Science Major 2 of SMAN 1 Kepulauan Sungai Raya of Bengkayang Regency in even semester of academic year of 2016/2017 which included in medium category. Related to the learning process through ICT-based learning group, the factors that able to determine the learning outcomes are the computer and internet connection availability, liquid crystal display (LCD) Projector, and sound system. Besides, the utilization of those media are highly correlated with students' interest which in turn can be potentially beneficial to improve their motivation during the learning process. (3) There are impacts or influences of the utilization of a learning process through ICT-based learning group on the students 
learning outcomes of economy subject in the SMAN 1 Sungai Raya Kepulauan of Bengkayang Regency.

The research results are in line with the research conclusion of Rahman (2010) which mentioned that there are influences or impacts of e-learning towards students learning activity. The difference between this research and the research of Rahman is regarding the variables used in which the independent variables used by Rahman are the learning process through electronic learning of individual (not in groups), the learning outcomes of students are in the from of individual assignments without any group and class discussion, the dependent variable is the learning activity of Civic Subject towards the $3^{\text {rd }}$ grade students of State Junior High School 1 of Sambas Regency in 2010. In acccordance with a study group of Lasswell and Kaplan (1999) which stated that a learning group cooperation that has a high awareness is characterized by feelings of solidarity and willingness of members to conduct something for the benefit of the group. These conditions can improve learning outcomes. According to Astra, Wahyuni, \& Nasbey (2015), the application of collaborative learning model of study group can profoundly improve learning process and learning outcome. The results of this study also support and confirm the viewpoint from Bidarian, Bidarian, \& Davoudi (2011), stating that the entrance of ICT into educational field is a valuable chance for performing some modifications and innovations resulted into efficiency increase and more effects of betterment result of the students' learning. Thus, ICTbased learning media are media of information used to deliver information associated to learning activities for helping students to easily understand the lessons which as a result would improve learning outcomes.

\section{CONCLUSIONS}

By referring to the mean score achieved by the students (67.86), the learning process through ICTbased learning group are included in good classification. This condition is supported by the availability of the teacher compatibility in performing decently the implementation steps of learning process through ICT-based learning group. The learning outcomes of economy subject of SMAN 1 Sungai Raya Kepulauan of Bengkayang Regency are 75.13 in average value which included in medium category. The learning process through ICT-based learning group generates an influence towards the learning outcomes of economy subject of SMAN 1 Sungai Raya Kepulauan of Bengkayang Regency.

Considering the above conclusions, there are certain recommendations triggered by the researcher: (1) For students, the use of internet should focus on activities to search for materials associated to learning activity. (2) For the teacher, they should: (a) develop the utilization of ICT media for the effectiveness and efficiency of achieving the learning objectives; (b) design students' learning materials that will be acquired through the internet in more systematic and psychological manners which perceived from the principles of learning in order to prepare for effective instruction; and (c) function the Internet for instructional purposes in which the information contained in the media should involve students both in the form of mental as well as in the form of real activities. (3) For the school principals, they should facilitate the availability of communication media such as computers and LCDs that are considered insufficient.

\section{REFERENCES}

[1] Al-Ansari, H. (2006). Internet use by the faculty members of Kuwait University. The Electronic Library, 24(6), 791-803.

[2] Astra, Made, I., Wahyuni, C., \& Nasbey, H. (2015). Improvement of Learning Process and Learning Outcomes in Physics Learning by using Collaborative Learning Model of Group Investigation at High School. Journal of Education and Practice, 6(11), 75-79.

[3] Balaji, M.S \& Chakrabarti, D. (2010). Student Interactions in Online Discussion Forum: Empirical Research from 'Media Richness Theory' Perspective. Journal of Interactive Online Learning, 9(3).

[4] Bidarian, Shabnam., Bidarian, Soheila., \& Davoudi, M.A. (2011). A Model for Aplication of ICT in The Process of Teaching and Learning. Procedia Social and Behavorial Sciences, 29, 1032-1041.

[5] Cohen, E. G. (1994). Restructuring the classroom: Conditions for productive small groups. Review of Educational Research, 64(1),1-35.

[6] Cohen, L., Manion, L., \& Morrison, K. (2007). Research methods in education ( $6^{\text {th }}$ ed.). New York: Taylor \& Francis e-Library.

[7] Dahlan, M. D. (2014). Beberapa Alternatrif interaksi belajar mengajar: Model-model mengajar. Bandung: Diponegoro.

[8] Holmes, Bryn., \& Gardner, John. (2006). E-learning: Concept and practice. Great Britain: TJ International, Padstow

[9] Joyce, B., \& Weil, M. (1990). Models of teaching. New Jersey: Prentice-Hall Inc.

[10] Lasswell, H.D. \& Kaplan, A. (1969). Power and society, a framework of political inquiry. London: New Haven.

[11] Moore, Jennifer D., \& Gunderson, David E. (2008). Group learning pedagogy and group selection. International Journal of Construction Education and Research, 4(1), 34-45. https://doi.org/10.1080/15578770801943893

[12] Nawawi, Hadari. (2015). Metode penelitian bidang ilmu sosial. Yogyakarta: Gajahmada.

[13] Sudjana, Nana. (2013). Penilaian hasil proses belajar mengajar. Bandung: PT Remaja Rosdakarya.

[14] Rahman, Abdul (2010). Pengaruh Pembelajaran Melalui Elektronik Learning Terhadap Aktivitas Belajar Siswa SMP Negeri 1 Sambas. (Skripsi). STKIP PGRI, Pontianak.

[15] Yusuf, M.O. (2005). Information and communication education: Analyzing the Nigerian national policy for information technology. International Education Journal, 6(3), 316-321. 